\title{
ANALISIS RESEPSI TERHADAP PERNIKAHAN MULTIKULTURAL
}

\author{
Jasmine Alya Pramesthi ${ }^{1}$
}

\begin{abstract}
ABSTRAK
Dengan pesatnya perkembangan teknologi, banyak orang yang menggunakan teknologi dengan cara membagikan pengalaman pribadinya secara tertulis atau audiovisual. Salah satunya adalah pengalaman yang dibagikan melalui YouTube oleh Keluarga Kimbab, Warga Negara Indonesia yang sedang mengalami pernikahan multikultural atau pernikahan campuran. Keluarga Kimbab juga kerap mengunggah berbagai konten yang menjelaskan tantangan yang dialami sebagai sebuah keluarga multikultural. Ini mencakup budaya yang berbeda, hingga batasan bahasa. Berbagai tanggapan yang diutarakan oleh penonton dari Keluarga Kimbab menunjukkan adanya ketertarikan pada kehidupan sehari-hari yang dilakukan oleh pasangan pernikahan multikultural. Hal ini sejalan dengan teori analisis resepsi oleh Stuart Hall yang menunjukkan bahwa makna dan penjelasan dalam pesan dapat dimaknai secara berbeda. Penelitian berikut ini dilakukan dalam melakukan penelitian tentang analisis resepsi audiens yaitu pelanggan dari Kimbab Family tentang pernikahan multikultural. Penelitian dilakukan dengan pendekatan kualitatif dengan paradigma konstruktivis. Pendekatan kualitatif digunakan untuk mendapatkan penjelasan yang mendalam tentang interpretasi yang diterima audiens. Data primer yang digunakan dalam penelitian ini diperoleh berdasarkan wawancara mendalam terhadap informan yang ditentukan melalui teknik purposive sampling. Melalui hasil penelitian yang telah dilakukan, peneliti dapat menyimpulkan bahwa terdapat perbedaan posisi oleh masing-masing audiens dalam melakukan resepsi, meliputi dominan-hegemoni, posisi negosiasi, dan posisi oposisi. Diharapkan dapat dilakukan penelitian lebih lanjut dengan menggunakan teori dan konsep lain dalam menjelaskan bagaimana keterlibatan audiens dalam konten serupa.
\end{abstract}

Kata kunci: pernikahan multikultural; analisis resepsi; stuart hall

\begin{abstract}
With the rapid development of technology, a lot of people are using technology by sharing their personal experiences in writing or audiovisual online. One of them is an experience shared via YouTube by Kimbab Family, An Indonesian citizen who is experiencing a multicultural marriage or a mixed marriage. Kimbab Family also often uploads various content that explains the challenges experienced as a multicultural family. This covers both different cultures, to the limitations of language. Various responses expressed by the audience from Kimbab Family showed that there is an interest in daily life carried out by couples from mixed marriages. This is in line with the theory of the reception analysis by Stuart Hall which shows that the meaning and explanation in the message can be interpreted differently. The following research was conducted in conducting a study on audience reception analysis, namely subscribers from Kimbab Family on multicultural marriage. The research was conducted with a qualitative approach with a constructivist paradigm. The qualitative approach is used to get an in-depth explanation of the interpretation received by the audience. The primary data used in this study was obtained based on in-depth interviews of informants determined through purposive sampling techniques. Through the results of the research that has been done, researchers can conclude that there are differences in position by each audience in conducting reception, including dominant-hegemonic, negotiated position, and oppositional position. It is expected that further research can be done using other theories and concepts in explaining how audience engagement in similar content.
\end{abstract}

Keywords: multicultural marriage; reception analysis; stuart hall

\footnotetext{
${ }^{1}$ Fakultas Ilmu Sosial dan Politik, Universitas Indonesia, Kota Jakarta Pust, Indonesia. Email: jasmine.alya@ui.ac.id
} 


\section{PENDAHULUAN}

Komunikasi merupakan suatu proses penyampaian informasi dari dari pengirim kepada penerimanya (Keikazeria \& Ngare, 2020). Proses komunikasi dilakukan sebagai bentuk interaksi manusia dalam perannya sebagai makhluk sosial. Komunikasi sendiri menjadi menarik karena interaksi yang dilakukan antar manusia tidak hanya terbatas pada individu-individu yang memiliki persamaan latar belakang, namun juga dapat melibatkan berbagai individu dengan bermacam-macam budaya. Dalam memahami serta melakukan implementasi dari konteks tersebut, komunikasi antar budaya merupakan konsep yang tepat.

Perbedaan budaya antara komunikator berfungsi sebagai batas atau penghalang yang harus diatasi jika ingin mencapai pemahaman dan kepuasan (Ellingsworth, 1977). Perbedaan antar budaya merupakan salah satu fokus penelitian komunikasi lintas budaya dan antar budaya. Perbedaan sering kali dipandang sebagai sumber kesalahpahaman dan konflik yang bermasalah (Xu, 2013). Komunikasi antar budaya melibatkan mempelajari perbedaan dan persamaan di dalam dan antar budaya. Kajian ini harus menyiratkan mengidentifikasi, memeriksa, dan memahami bagaimana budaya dan komunikasi membentuk satu sama lain secara dinamis (Shenoy-Packer, 2017). Penelitian dalam komunikasi antar budaya melibatkan penyelidikan interaksi interpersonal dari latar belakang bahasa dan budaya yang berbeda. Bentuk kontak antarbudaya ini bervariasi. Ini mungkin tatap muka atau melibatkan komunikasi melalui wacana tertulis dan mungkin fokus pada perilaku verbal atau nonverbal, sikap atau persepsi orang-orang dari latar belakang budaya dan bahasa yang berbeda berinteraksi satu sama lain (Jackson, 2014). Selain itu, saat ini penelitian komunikasi antar budaya lebih relevan secara pragmatis daripada sebelumnya, mengingat peningkatan mobilitas global dan aksesibilitas teknologi yang memfasilitasi kontak antar budaya lintas benua (Arasaratnam, 2015). Salah satu implementasi dalam kontak antar budaya yaitu dengan adanya pernikahan multikultural.

Pernikahan multikultural juga disebut sebagai pernikahan campuran. Globalisasi informasi, ekonomi, pendidikan dan transportasi menjadikan batas negara tidak lagi menjadi penghalang interaksi. Hal ini berdampak pada semakin banyaknya pernikahan antar negara hampir di seluruh dunia. Di Indonesia, perkawinan campuran dapat terjadi dalam dua bentuk, yaitu: pertama, wanita Indonesia (selanjutnya disebut WNI) menikah dengan pria asing (selanjutnya disebut orang asing); kedua, pria Indonesia yang menikahi wanita asing. Perbedaan kewarganegaraan di antara para pihak itulah yang membedakan pernikahan campuran (Bakarbessy \& Handajani, 2012).

Pernikahan tidak hanya menyatukan dua kepribadian yang berbeda, tetapi juga menggabungkan dua budaya bangsa yang berbeda. Saat menikah dengan pasangan yang berbeda ras, individu akan menjumpai budaya etnis sebelum, selama, dan setelah proses pernikahan. Pertemuan budaya dalam perkawinan seringkali menimbulkan masalah, terutama pada saat proses penyesuaian pasangan dan keluarganya masing-masing (Hidayati, 2017). Indonesia sendiri dikenal memiliki budaya dalam pernikahannya, yaitu

Dalam perkawinan campur antar individu dengan latar belakang etnis yang berbeda, tentunya setiap pasangan akan memiliki tantangan yang menarik. Setiap pasangan memiliki cara komunikasinya masing-masing. Oleh karena itu, baik laki-laki maupun perempuan membutuhkan cara komunikasi yang tepat untuk menyelesaikan konflik dalam kehidupan perkawinan, terutama dalam perkawinan internasional, karena laki-laki dan perempuan biasanya sangat berbeda dalam komunikasi (Sihombing \& Yusuf, 
2013). Dalam menyelesaikan konflik yang terjadi, Tili \& Barker) 2015). menemukan bahwa pasangan multikultural menunjukkan kemauan untuk mengubah perspektif individu mereka dan untuk secara terbuka mengatasi konflik, menggunakan kompetensi komunikasi antar budaya yang telah mereka kembangkan, sambil menarik motivasi dari keinginan mereka untuk pertumbuhan pribadi dan mengatasi kesulitan yang terkait dengan kefasihan bahasa yang terbatas dan gaya komunikasi yang bertentangan secara diametral.

Dengan pesatnya perkembangan teknologi, semakin banyak orang menggunakan teknologi ini dengan berbagi pengalaman pribadi mereka secara tertulis atau audiovisual secara online. Komunikasi dapat dilakukan tanpa adanya batasan ruang dan waktu (Asri, 2018). Salah satunya adalah pengalaman yang dibagikan oleh Warga Negara Indonesia (WNI) melalui YouTube, terutama peran istri yang mengalami perkawinan multikultural atau pernikahan campuran dalam kehidupannya, kreator tersebut adalah pemilik YouTube channel Kimbab Family. Kimbab Family merupakan salah satu content creator pada platform YouTube dengan 1.4 juta subscribers. YouTube channel Kimbab Family dikelola oleh satu pasangan pernikahan campuran, dimana Jay sebagai suami dengan kewarganegaraan Korea Selatan dan Gina sebagai suami dengan kewarganegaraan Indonesia. Dalam deskripsi yang tertera pada YouTube channelnya, Kimbab Family menjelaskan bahwa mereka merupakan keluarga multikultural dengan tiga anak yang tinggal di Seoul, Korea Selatan. Videovideo yang diunggah oleh channel tersebut mencakup kegiatan sehari-hari sebagai suatu keluarga, aktivitas yang dilakukan anak-anak, serta aktivitas perjalanan di Korea Selatan. Kimbab Family juga kerap mengunggah berbagai konten yang menjelaskan tantangantantangan yang dialami sebagai keluarga multikultural. Hal tersebut mencakup baik budaya yang berbeda, hingga keterbatasan dalam berbahasa. Salah satu video dengna jumlah penonton terbanyak dari YouTube channel Kimbab Family yang diunggah pada Juni 2020 dengan jumlah penonton 8.8 juta adalah sebagai berikut

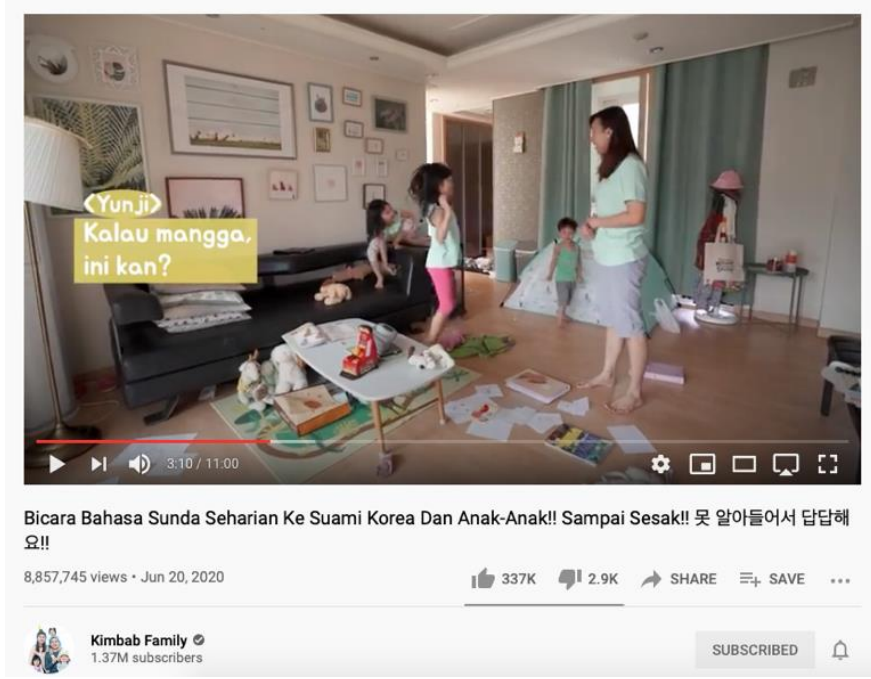

Gambar 1. Video YouTube Kimbab Family

Konten dalam video tersebut menceritakan tantangan Kimbab Family sebagai keluarga multikultural, yaitu dalam keterbatasan penggunaan bahasa. Gina yang merupakan WNI dengan suku
Sunda telah terbiasa menggunakan Bahasa Sunda sebagai bahasa sehariharinya di keluarganya sebelum menikah. Karena menikah dengan Jay yang berkewarganegaraan Korea, maka bahasa 
yang digunakan sehari-hari dengan keluarganya adalah Bahasa Korea dan Bahasa Indonesia. Dengan berkomunikasi menggunakan Bahasa Sunda yang bukan bahasa sehari-hari keluarganya di Korea membuat Jay dan anak-anaknya tidak mengerti apa yang dibicarakan oleh Gina.
Respon yang diberikan oleh penonton pun beragam, dari banyaknya jumlah likes yaitu 337 ribu serta lebih dari 23 ribu komentar dalam video tersebut (diakses pada 13 Desember 2020). Berikut merupakan komentar-komentar yang diberikan oleh penonton

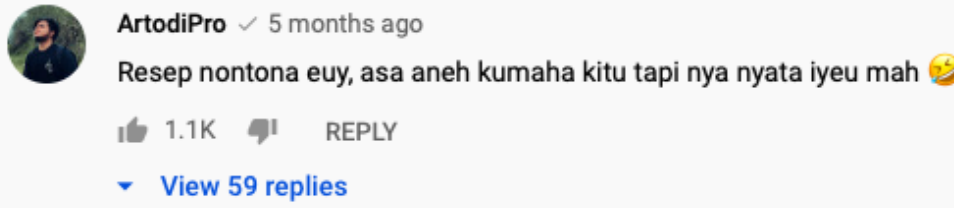

Figure 2. Komentar YouTube Kimbab Family

$\begin{array}{lll}\text { Dalam } & \text { komentar tersebut } & \text { lebih dari } 1000 \text { orang dengan } 1100 \text { likes. } \\ \text { menjelaskan bahwa salah satu } & \text { Penonton merasa asing dalam } \\ \text { penontonnya sangat menyukai konten } & \text { menontonnya, namun menjadi menarik } \\ \text { tersebut, komentar tersebut disetujui oleh } & \text { karena hal tersebut terjadi secara nyata. }\end{array}$

\section{W} Wanda Rizqia 2 months ago

Figure 3. Komentar YouTube Kimbab Family

Sedangkan pada komentar di atas menjelaskan salah satu percakapan dalam video tersebut dimana anggota keluarga merasa asing dengan kosa kata Bahasa Sunda yang digunakan oleh Gina, dimana dalam Bahasa Sunda "mangga" diartikan sebagai "silakan" sedangkan dalam Bahasa Indonesia, "mangga" berartikan buah.

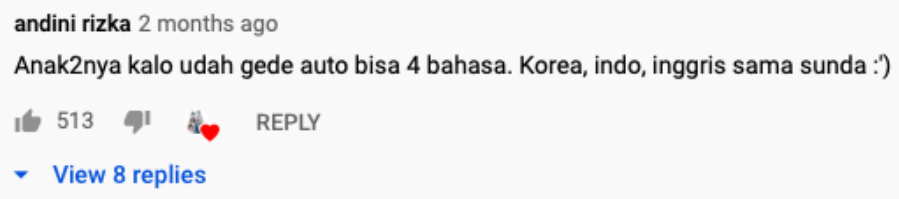

Figure 4. Komentar YouTube Kimbab Family

Sedangkan dalam komentar berikut menjelaskan bahwa penonton memiliki anggapan dengan adanya pernikahan campuran akan membuat anak-anak dalam keluarga tersebut akan mahir dalam berbagai bahasa yang digunakan oleh kedua orang tuanya.

Berbagai respon yang dikemukakan oleh penonton dari Kimbab Family menunjukkan bahwa adanya ketertarikan dengan kehidupan sehari-hari yang dilakukan oleh pasangan dari pernikahan campuran. Hal tersebut selaran dengan teori dari analisis resepsi oleh Stuart Hall yang menunjukkan bahwa makna serta penjelasan dalam pesan tersebut bisa diartikan berbeda. Dalam hal ini, penonton memiliki interpretasinya sendiri untuk konten yang telah ditayangkan. Hal ini yang mendorong terjadinya interpretasi yang beragam dari teks-teks media selama proses produksi serta penerimaan (resepsi). Encoding menjelaskan suatu proses penerjemahan 
yang dilakukan oleh produsen mengenai suatu hal, serta decoding menjelaskan suatu proses menerjemahkan yang dilakukan oleh audiens terhadap pesan yang ia peroleh dari produsen. Pemaknaan tersebut dibagi ke dalam tiga bagian yang merupakan

1. Dominant-hegemonic position dimana audiens menerima serta mereproduksi kode teks yang sesuai dengan produser pesan, audiens pada hal ini memiliki pegangan dalam makna yang diberikan dalam media.

2. Negotiated position dimana audiens menerima pemaknaan secara luas dari sebagian kode teks namun terkadang melakukan penentangan atau mengubah makna sesuai bagaimana cara pandang dari audiens tersebut.

3. Oppositional position, dimana audiens melakukan pengembangan interpretasi yang benar-benar berbeda dari kode teks. Hal ini terjadi apabila audiens ditempatkan pada situasi sosial yang kontras dengan kode teks dominan yang menjadikan audiens melakukan penolakan atas teks tersebut serta audiens dapat memberikan pengajuan berupa alternatif kode yang berbeda (Davis, 2004).

Terdapat beberapa studi-studi terdahulu yang memberikan penjabaran mengenai keluarga multikultural, diantaranya yang ditemukan oleh (Hadawiyah, 2016). yang menjelaskan bahwa budaya keluarga kawin campur menjadi peleburan yang unik, terutama ketika semua pihak berusaha menyelesaikan masalah keluarga. Sebagai permulaan, kedua belah pihak mengatakan sebelum mereka menikah bahwa keluarga dan lingkungan tumbuh telah membuat orang memahami ras lain. Selain itu, Tili \& Barker (2015) mengemukakan bahwa komunikasi pasangan antar budaya terutama dipengaruhi oleh pertumbuhan pribadi, kefasihan bahasa, dan perbedaan antara gaya komunikasi konteks tinggi dan konteks rendah.

Perbedaan dengan penelitian- penelitian berikut, dalam studi ini peneliti hendak melakukan penelitian berdasarkan sudut pandang individu lainnya dalam memahami konteks komunikasi antar budaya dalam pernikahan multikultural. Subscribers dari YouTube channel Kimbab Family menjadi subjek penelitian ini, dimana penerimaan makna mengenai pernikahan multikultural ditinjau melalui konsep analisis resepsi oleh Stuart Hall guna menemukan penjelasan mengenai pemaknaan audiens mengenai pernikahan multikultural berdasarkan video-video yang diunggah oleh Kimbab Family.

Berdasarkan pemaparan berikut, peneliti bertujuan dalam melakukan studi mengenai analisis resepsi audiens yaitu subscribers dari Kimbab Family mengenai pernikahan multikultural dengan judul penelitian "Analisis Resepsi Terhadap Pernikahan Multikultural (Studi pada Subscribers YouTube Channel Kimbab Family).

\section{METODOLOGI}

Penelitian ini menggunakan pendekatan kualitatif dengan paradigma konstruktivistik yang merupakan orientasi terhadap realitas sosial yang mengasumsikan keyakinan dan makna yang diciptakan dan digunakan orang secara mendasar membentuk realitas (Djamba \& Neuman, 2014). Pendekatan kualitatif digunakan untuk mendapatkan penjelasan mendalam mengenai interpretasi yang diterima oleh audiens. Subscribers dari Kimbab Family dipilih menjadi informan dalam penelitian ini karena dianggap memiliki keterlibatan dalam menyaksikan tayangan-tayangan yang diunggah oleh YouTube channel Kimbab Family. Guna mendapatkan hasil dari pemaknaan yang diberikan audiens, peneliti menggunakan metode analisis resepsi dengan teknik yang digunakan ialah in-depth interview kepada lima informan. Indepth interview yaitu wawancara mendalam yang mengajukan tiga jenis pertanyaan dalam wawancara lapangan, dapat berupa pertanyaan deskriptif, struktural, dan kontras (Djamba \& Neuman, 2014).

Data primer yang digunakan dalam 
studi ini diperoleh berdasarkan in-depth interview terhadap informan yang ditentukan melalui teknik purposive sampling yang merupakan sampel nonrandom di mana peneliti menggunakan berbagai metode untuk menemukan semua kemungkinan kasus dari populasi yang sangat spesifik dan sulit dijangkau (Djamba \& Neuman, 2014). Kriteria-kriteria informan yang ditentukan sebagai informan ialah telah menjadi subscribes Kimbab Family minimalnya selama satu tahun, serta rutin menyaksikan tayangan yang diunggah oleh Kimbab Family. Guna mendukung data primer yang diperoleh, peneliti memperoleh data sekunder melalui kajian pustaka serta dokumentasi-dokumentasi yang diperoleh baik melalui buku, penelitian terdahulu, serta data-data melalui internet.

Dalam melakukan in-depth intrerview, informan digali informasinya untuk menjawab mengapa serta bagaimana berdasarkan informasi yang diperoleh. Informan diharapkan untuk dapat menceritakan ulang tayangan video yang telah disaksikan oleh informan. Selain itu, peneliti juga melakukan observasi serta mencatat dan mengkritisi informasiinformasi yang didapatkan untuk mendukung data dimana nantinya melibatkan peneliti menjadi bagian yang dikaji.

\section{HASIL DAN DISKUSI}

Hasil dari studi berikut diperoleh berdasarkan data primer yang digunakan yakni wawancara mendalam kepada lima subscribers Kimbab Family serta data sekunder yang diperoleh dari berbagai sumber yang ditemukan. Berdasarkan hasil penelitian, ditemukan bahwa pemaknaan yang dilakukan oleh audiens terhadap konten pernikahan multikultural oleh Kimbab Family berbeda-beda. Kelima informan diketahui telah berlangganan channel Kimbab Family lebih dari satu tahun dan aktif menonton video pada channel berikut setiap Kimbab Family mengunggah video terbaru. Selain itu, masing-masing informan memiliki motivasi yang beragam untuk menjadi penonton YouTube Kimbab Family. Dua informan menjelaskan bahwa alasan untuk memutuskan subscribe channel Kimbab Family karena sudah memiliki ketertarikan dengan negara Korea Selatan, satu informan memutuskan untuk subscribe berdasarkan rekomendasi dari orang terdekatnya, serta satu informan menemukan video Kimbab Family dari beranda YouTube.

Berdasarkan pemikiran oleh Stuart Hall yang membagi resepsi audiens kepada tiga jenis posisi, peneliti melakukan preferred reading terhadap hasil analisis berdasarkan transkrip wawancara yang hasilnya menempatkan audiens berada pada posisi yang berbeda-beda sebagaimana dijelaskan sebagai berikut

\section{Dominant-hegemonic position}

Menurut Davis (2004) posisi berikut menempatkan audiens dalam menerima kode teks sesuai dengan apa yang diinginkan oleh produsen pesan. Dalam hal berikut, produsen pesan yakni Kimbab Family hendak mengemukakan pengalamannya dalam menjalani pernikahan multikultural. Informan Dessy, Lintang, dan Lidia merasakan bahwa pesan yang dikemukakan oleh Kimbab Family dapat diterima secara baik oleh informan. Kemudian informan Dessy, Lintang, dan Lidia pun mengungkapkan harapannya untuk semakin banyak konten kreator serupa untuk dapat aktif membagikan pengalaman pernikahan multikulturalnya di media sosial guna menambah wawasan penonton lebih luas mengenai perbedaan budaya yang dialami. Ketiga informan setuju bahwa dengan adanya pernikahan multikultural maka tantangan yang dihadapi oleh pasangan tersebut akan semakin besar dibandingkan pernikahan dengan budaya yang sama.

"Udah jelas pasti bakal lebih menantang dibandingin nikah dengan orang Indonesia lagi. Tantangan-tantangannya pasti bakal sama banget kaya (yang dialami oleh) Kimbab Family, kebingungan anakanaknya akan menggunakan bahasa ibu yang mana, kalau untuk sekarang sih 
(Kimbab Family) belum bingung kewarganegaraan anak-anaknya bakal ngikut Eomma atau Appa nya, cuman kalau udah diatas 18 tahun baru akan jadi dilemma menurutku" (Wawancara Dessy, 24 Desember 2020).

Pernyataan informan berikut sesuai dengan apa yang dijelaskan oleh Kimbab Family pada video-video yang diunggah, dimana menjelaskan tantangan-tantangan yang dihadapi dalam menjalankan pernikahan multikultural. Melalui videovideo yang diunggah oleh Kimbab Family, ketiga informan juga merasakan adanya engaruh dalam kehidupan pribadinya, yakni adanya ketertarikan dalam dirinya untuk memiliki pasangan dengan beda budaya.

"Karena dari dulu juga aku punya preferensi kesitu (untuk memiliki pasangan berbeda budaya), makanya aku lihat video Mama Gina (Kimbab Family) jadi tertarik juga. Walaupun tantangannya lebih berat, tapi pasti manfaatnya juga gak kalah besar untuk membesarkan anak dengan dua perspektif yang beda biar pikirannya lebih terbuka" (Wawancara Lidia, 22 Desember 2020).

Berdasarkan pernyataan informan berikut yang setuju dengan apa saja yang diungkapkan oleh Kimbab Family sebagai produsen teks, maka memperkuat posisi audiens yang berada di dominanthegemonic untuk dapat menerima kode teks sesuai dengan apa yang disampaikan oleh produsen pesan.

\section{Negotiated Position}

Negotiated position dijelaskan oleh Davis (2004) bahwa audiens menerima pemaknaan secara general dari sebagian kode teks namun adanya pertentangan yang dirasakan sebagaimana cara pandang audiens yang berbeda. Informan Citra dapat menerima pesan yang dikemukakan oleh Kimbab Family secara baik. Serupa dengan informan Dessy, Lintang, dan Lidia yang tergabung pada posisi dominanthegemonic, informan Citra juga mengungkapkan harapannya untuk semakin banyak konten kreator serupa untuk dapat aktif membagikan pengalaman pernikahan multikultural, namun alih-alih untuk menambah wawasan penonton seperti ketiga informan sebelumnya, informan Citra mengungkapkan bahwasanya hal tersebut diharapkan oleh informan Citra sebagai referensi hiburannya karena konten-konten mengenai Indonesia menghibur bagi informan dalam mengisi waktu senggang. Infoman citra juga sepakat bahwa tantangan yang dihadapi oleh pasangan multikultural akan lebih besar dibandingkan pernikahan dengan warga negara yang sama.

"Iya pasti jauh lebih susah (tantangannya) apalagi Gina dibesarkan oleh keluarga (suku) sunda yang pake Bahasa Sunda sehari-hari, sedangkan Jay orang Korea yang bisanya (bicara) Bahasa Indonesia, bukan Bahasa Sunda. Apalagi kadang kalau orang tua suka khawatir kalau anaknya jauh dari orang tua, taunya anaknya dibawa ke negara orang, harus adaptasi lagi. Adaptasi lagi nya sih yang jadi hambatan. Tapi mau menikah sama siapapun juga adaptasi bakal jadi hambatan karena tiap keluarga beda-beda budayanya, jadi sebenarnya pernikahan multikultural maupun sesama warga negara juga samasama punya tantangan, yang beda Cuma jaraknya" (Wawancara Citra, 22 Desember 2020).

Secara umum informan menyetujui poin-poin yang dijelaskan produsen pesan di tiap videonya mengenai tantangan dan hambatan dalam menjalankan pernikahan multikultural. Namun informan memiliki sudut pandang yang berbeda, yakni informan memutuskan untuk menyaksikan tayangan bukan untuk menambah wawasan mengenai pernikahan multikultural, namun sebagai bahan hiburan. Kemudian informan menjelaskan bahwa semua pernikahan memiliki kesulitannya masing-masing dalam beradaptasi, baik dalam pernikahan multikultural atau bukan. Berbeda dengan ketiga informan pada posisi dominanthegemonic sebelumnya yang terpengaruh akan konten Kimbab Family untuk dapat memiliki pasangan multikultural, informan Citra merasakan bahwa konten video yang diunggah tidak berpengaruh secara 
signifikan bagi dirinya.

Berdasarkan pernyataan informan berikut yang menyetujui sebagian kode teks yang diungkapkan oleh Kimbab Family namun memiliki sudut pandang yang berbeda telah memperkuat posisi audiens untuk berada di negotiated position.

\section{Oppositional Position}

Pada oppositional position menurut Davis (2004) menempatkan posisi audiens dalam melakukan pengembangan interpretasi yang berbeda dari kode teks dan adanya situasi sosial yang kontras sehingga adanya penolakan dan pengajuan alternatif kode yang berbeda. Berbeda dari keempat informan sebelumnya, informan Hani memiliki situasi yang menarik dimana walaupun ia seorang subscriber dari YouTube channel Kimbab Family, namun ia memiliki pandangan yang kontras dengan apa yang disampaikan oleh Kimbab Family.

Kimbab Family dalam videonya menjelaskan perbedaan-perbedaan budaya maupun bahasa yang menjadi tantangan dalam menjalankan pernikahan multikultural. Perbedaan budaya tersebut dirasakan juga oleh ketiga anaknya yang kesulitan dalam mengeja nama Ibunya yang berkewarganegaraan Indonesia, dilemma untuk menentukan Bahasa Korea sebagai bahasa ibu dalam percakapan sehari-hari. Tantangan tersebut telah diraskaan dari bagaimana cara berkomunikasi dengan pasangan tanpa menggunakan bahasa ibu masing-masing pada awal perkenalan, hingga memutuskan untuk menikah karena banyaknya pertimbangan dari perbedaan budaya yang dialami. Dalam salah satu videonya juga dijelaskan bahwa Gina sebagai Warga Negara Indonesia lebih nyaman untuk menggunakan Bahasa Indonesia apabila berkomunikasi dengan ketiga anaknya karena menurutnya pesannya akan lebih tersampaikan secara sempurna, selain itu anak-anak juga perlu berkomunikasi dengan keluarga di Indonesia.

Informan Hani walaupun telah memutuskan menjadi penonton reguler dari video-video yang diunggah oleh Kimbab Family sebagai hiburannya, ia mengungkapkan bahwa ia tidak begitu mengharapkan untuk adanya konten-konten kreator serupa yang mengunggah kisah pernikahan multikulturalnya di YouTube. Alasan informan Hani memutuskan untuk menjadi subscriber Kimbab Family karena ia merasa terhibur dengan tingkah ketiga anak dari Kimbab Family, bukan secara khusus dikarenakan untuk menyaksikan pengalaman pernikahan multikultural yang dibagikan.

"Aku sejujurnya kurang setuju kalau misalnya jadi makin banyak YouTuber yang nikah sama WNA makin aktif, karena gimana ya, dari sekian banyaknya yang upload tuh menurutku banyak yang clickbait di judul videonya dengan bawabawa Indonesia biar banyak yang nonton, padahal isinya ya biasa banget, sama aja kaya pasangan Indonesia. Tapi kalau Kimbab Family itu kontennya menurutku menarik karena anak-anaknya lucu banget dan isinya nggak cuma reaction video, dan nggak clickbait ngejual "Indonesia" atau "Suami Bule" dalam judulnya kayak YouTuber lainnya. Aku kurang suka aja kayak misalnya ada judul "Suami bule reaction video Indonesia" ya kalau gitu apa bedanya dengan sesama orang Indonesia reaction video Indonesia?" (Wawancara Hani, 24 Desember 2020).

Berdasarkan pernyataan informan Hani berikut merupakan pengembangan opini yang ia miliki mengenai content creator yang merupakan pasangan multikultural. Informan Hani menjelaskan bahwasanya tidak seluruh audiens dari Kimbab Family memiliki harapan dan motivasi yang sama. Selain itu, informan Hani juga memiliki pendapat yang bertentangan mengenai tantangan yang dihadapi oleh pasangan multikultural.

"Ya menurutku mau nikah sama warga negara manapun juga sama aja, mau nikah sesama Warga Negara Indonesia juga perbedaan budayanya kontras kok. Misalnya aku kan orang Padang, nikah sama orang Jawa, itu kan juga udah beda banget secara budaya dan bahasanya. Walaupun sama-sama orang Indonesia, kalau misalnya masing-masing keluarga 
bahasa ibunya bahasa daerah masingMakanya aku nggak begitu meromantisasi pernikahan multikultural. Sama aja kayak aku pindah ke Jawa dengan Gina pindah ke Korea, pasti harus ada proses penyesuaian supaya bisa diterima oleh lingkungan. Cuman emang kalau konten mereka (Kimbab Family) itu seru banget parenting-nya" (Wawancara Hani, 24 Desember 2020). Berdasarkan pernyataan informan berikut, informan memiliki opini yang kontras mengenai pernikahan multikultural yang dijelaskan oleh Kimbab Family dalam video-video yang diunggah. Informan Hani mengungkapkan bahwa tantangan yang dihadapi dalam pernikahan multikultural tidak akan memiliki perbedaan yang kontras dengan pernikahan dengan kesamaan warganegara karena sama-sama harus menjalani proses adaptasi. Hal tersebut sesuai dengan yang diungkapkan oleh Heryadi \& Silvana (2013) bahwa bagi imigran yang melakukan imigrasi ke tempat yang baru bagi dirinya maka perlu untuk menjaga kelangsungan hidupnya dan berusaha agar dapat diterima oleh lingkungan sekitar sebagai bagian dari anggota masyarakat karena perbedaan budaya yang benar-benar baru merupakan situasi yang harus dihadapi oleh imigran.

Berbeda dengan ketiga informan pada posisi dominant-hegemonic sebelumnya yang terpengaruh akan konten Kimbab Family untuk dapat memiliki pasangan multikultural, informan Hana tidak merasakan adanya pengaruh signifikan bagi dirinya. Maka dari itu, keseluruhan pernyataan informan Hana menempatkan dirinya pada oppositional position karena adanya perbedaan sudut pandang yang kontras.

\section{KESIMPULAN}

Dalam menjelaskan bagaimana resepsi yang dilakukan oleh audiens mengenai pernikahan multikultural, penelitian berikut dilakukan pada lima subscribers YouTube Kimbab Family. Melalui hasil penelitian yang telah dilakukan, peneliti dapat menyimpulkan masing, berarti harus ada adaptasi lagi. bahwa adanya perbedaan posisi oleh tiap audiens dalam melakukan resepsi.

Pada dominant-hegemonic position, audiens menerima secara baik kode teks mengenai tantangan pernikahan multikultural sesuai yang disampaikan oleh Kimbab Family sebagai produsen teks. Adanya pengaruh yang diberikan oleh Kimbab Family mendorong khalayak untuk tertarik dalam menjalani pernikahan multikultural serta adanya harapan untuk adanya kreator selanjutnya yang juga aktif dalam membagikan pengalamanya. Kemudian pada negotiated position, audiens menerima kode teks mengenai tantangan pernikahan multikultural namun adanya opini pribadi yang menjelaskan bahwa setiap pernikahan memiliki tantangannya masing-masing, serta audiens pada posisi berikut tidak terpengaruh untuk tertarik memiliki pasangan beda budaya. Selanjutnya pada oppositional position yakni adanya sudut pandang yang kontras dari audiens mengenai tantangan pernikahan multikultural, audiens menyampaikan bahwa tidak adanya perbedaan yang kontras dari pernikahan multikultural dengan pernikahan lainnya apalagi Indonesia memiliki beragam budaya yang berbeda-beda.

Berdasarkan hasil penelitian, diharapkan penelitian selanjutnya dapat melakukan penelitian menggunakan teori maupun konsep lainnya dalam menjelaskan bagaimana keterlibatan audiens dalam konten-konten serupa, misalnya dengan menggunakan teori Uses and Gratification untuk menjelaskan motivasi subscribers ataupun melakukan studi mengenai fandom yang terbentuk dari YouTube channel Kimbab Family. Sedangkan untuk saran praktis, peneliti menemukan bahwa informan mengungkapkan masih banyaknya content creator serupa yang menggunakan Indonesia sebagai clickbait namun kontennya tidak memiliki ciri khas, melalui temuan tersebut peneliti menyarankan bagi content creator lainnya untuk dapat menemukan ciri khas unik dari tiap konten yang diunggah untuk menjadi 
diferensiasi channel YouTube-nya dibandingkan yang lain.

\section{DAFTAR PUSTAKA}

Arasaratnam, L. A. (2015). Research in Intercultural Communication: Reviewing the Past Decade. Journal of International and Intercultural Communication, 8(4), 290-310.

https://doi.org/10.1080/17513057.2015.1 087096

Asri, R. H. (2018). Strategi Komunikasi Humas Polda Polda D. I. Yogyakarta Melalui Skill Digital Savvy Di Era Disruptif. Expose: Jurnal Ilmu Komunikasi, 1(2), 95. https://doi.org/10.33021/exp.v1i2.432

Bakarbessy, L., \& Handajani, S. (2012). Kewarganegaraan Ganda Anak Dalam Perkawinan Campuran Dan Implikasinya Dalam Hukum Perdata Internasional. Perspektif, $17(1), \quad 1$. https://doi.org/10.30742/perspektif.v17i1. 89

Davis, H. (2004). Understanding Stuart Hall. Sage Publications.

Djamba, Y. K., \& Neuman, W. L. (2014). Social Research Methods: Qualitative and Quantitative Approaches. In Pearson Education Limited. https://doi.org/10.2307/3211488

Ellingsworth, H. W. (1977). Conceptualizing Intercultural Communication. Annals of the International Communication Association, 1(1), 99-106. https://doi.org/10.1080/23808985.1977.1 1923674

Hadawiyah. (2016). Komunikasi Antarbudaya Pasangan Beda Etnis (Studi Fenomenologi Pasangan beda Etnis Suku Sulawesi - Jawa di Makassar). Jurnal Lentera Komunikasi, 2(1).

Heryadi, H., \& Silvana, H. (2013). Komunikasi
Antarbudaya Dalam Masyarakat Multikultur. Jurnal Kajian Komunikasi, l(1), https://doi.org/10.24198/jkk.vol1n1.9

Hidayati, S. (2017). Penyesuaian Budaya dalam Perkawinan. JOMSIGN: Journal of Multicultural Studies in Guidance and Counseling, $\quad 1(1), \quad 83$. https://doi.org/10.17509/jomsign.v1i1.60 53

Jackson, J. (2014). Introducing Language and Intercultural Communication. Routledge.

Keikazeria, V. M., \& Ngare, F. (2020). Komunikasi Interpersonal Ibu dan Anak dalam Pembentukan Karakter Beribadah Anak ( Studi Kualitatif Pada Ibu dan Anak di Lingkungan Perumahan Pondok Giri Harja Endah Kelurahan Jelekong ). Jurnal Communio: Jurnal Ilmu Komunikasi, IX(2), 1613-1629.

Shenoy-Packer, S. (2017). Intercultural communication. In Communication Theory: Second Edition (pp. 403-419). https://doi.org/10.4324/9781315716282-7

Sihombing, S., \& Yusuf, E. A. (2013). Gambaran Pola Komunikasi Dalam Penyelesaian Konflik Pada Wanita Yang Menikah Dengan Pria Asing (Barat). PREDICARA, 2(1).

Tili, T. R., \& Barker, G. G. (2015). Communication in Intercultural Marriages: Managing Cultural Differences and Conflicts. Southern Communication Journal, 80(3), 189-210. https://doi.org/10.1080/1041794X.2015.1 023826

$\mathrm{Xu}$, K. (2013). Theorizing Difference in Intercultural Communication: A Critical Dialogic Perspective. Communication Monographs, 80(3), 379-397. https://doi.org/10.1080/03637751.2013.7 88250 